\title{
Threats to the Rule of Law: The Pitfalls of the Cooperation and Verification Mechanism
}

\author{
Radosveta Vassileva
}

The Juncker Commission has recently indicated that the experienced gained from the Cooperation and Verification Mechanism (CVM) is relevant when addressing rule of law challenges in all Member States. It has also proposed to monitor the rule of law in all Member States. Bulgaria and Romania are the only EU members which are subjected to the CVM because they did not fully fulfill the accession criteria on the rule of law when they acceded to the Union in 2007. In 2018, the Juncker Commission identified important progress in Bulgaria and promised to lift the mechanism for the country before the end of its term. Yet, has the CVM helped Bulgaria strengthen its rule of law? By using Bulgaria's CVM as a case study, this article showcases some of the pitfalls of this mechanism, including the quality of the Commission's monitoring - namely, that Bulgaria's rule of law declined despite the CVM. Dissecting this phenomenon is important not just in light of the Commission's own call to study the experience gained from the CVM, but also in view of growing concerns about dual standards in enforcing EU values in the Union.

Keywords: Rule of law; EU values; European Convention on Human rights; Cooperation and Verification Mechanism (CVM); Romania; Bulgaria; Law reform; Judicial independence; Political judicial council; Political Prosecutor's Office

\section{INTRODUCTION}

In a recent Communication dedicated to strengthening the rule of law in all Member States of the European Union (EU), the Commission stressed that ' $[\mathrm{t}] \mathrm{he}$ experience gained [from the Cooperation and Verification Mechanism (CVM)] is relevant when addressing rule of law challenges in all Member States'. In a subsequent Communication, which puts forward a 'blueprint for action' in the area of rule of law, the Commission emphasized its intent to monitor the rule of law in all Member States and publish annual reports. ${ }^{2}$

When Bulgaria and Romania acceded to the EU in 2007, they did not entirely fulfill the accession criteria. 3 That is why, the Commission placed them under a special monitoring procedure, known as the CVM, which was supposed to help these Member

\footnotetext{
${ }^{1}$ Communication on 'Further strengthening the Rule of Law within the Union: State of play and possible next steps', $\operatorname{COM}(2019) 163$ final, at 5 .

${ }^{2}$ Communication on 'Strengthening the rule of law within the Union: A blueprint for action', COM(2019) 343 final, at 9-12.

3 The so-called Copenhagen criteria cover three clusters: political criteria (democracy, rule of law, etc.), economic criteria (market economy, competition, etc.) and administrative criteria.
} 
States catch up with others by achieving benchmarks set by the Commission. ${ }^{4}$ Bulgaria has to satisfy six benchmarks - judicial independence, legal framework, continued judicial reform, high-level corruption, general corruption, and organized crime. 5 In turn, Romania has to satisfy four benchmarks - judicial independence and judicial reform, integrity framework, high-level corruption, and general corruption. ${ }^{6}$

In 2016, the President of the Commission Jean-Claude Juncker told reporters that 'he had always said ... that Bulgaria would exit the Mechanism during the mandate of [his] Commission'.7 Bulgaria's 2018 CVM report declared three benchmarks 'provisionally closed' - judicial independence, legal framework, and organized crime. ${ }^{8}$ After it was published, the Commission issued a statement quoting the Commissioner for the Rule of Law Frans Timmermans who said that if progress continued, the CVM would be lifted for Bulgaria in 2019.9

Did the CVM help Bulgaria strengthen its rule of law? This article uses Bulgaria's CVM as a case study to demonstrate some of the pitfalls of this monitoring - namely, it argues that Bulgaria's rule of law deteriorated despite the CVM. Exploring the weaknesses of this mechanism seems important in light of the growing concerns that the CVM reports do not match reality, ${ }^{10}$ the recent body of literature on democratic backsliding and strengthening the rule of law, ${ }^{11}$ the criticism that EU institutions did not address the rule

4 The benchmarks are set in two separate Decisions of 13 December 2006 - one concerning Bulgaria (2006/929/EC) and another concerning Romania (2006/928/EC); It is interesting that these are the only two Member States placed under the CVM - Croatia, which joined the EU in 2013, was not subjected to this mechanism.

5 Ibid.

${ }^{6}$ Ibid.

7 Juncker: CVM on Bulgaria to Be Lifted by End-2019 (2016) https://www.novinite.com/articles/173175/Juncker\%3A+CVM+on+Bulgaria+to+Be+Lifted+by+End2019.

${ }^{8} \mathrm{COM}(2018) 850$ final.

9 Commission press release IP/18/6364, 13 November 2018.

10 After the Commission published the 2018 CVM reports, Magistrats Européens pour la Démocratie et les Libertés (MEDEL) sent a letter to the Commission in which it 'raise[d] serious concerns regarding the conclusions expressed in those reports which, from its perspective, [did] not match the realities in both countries'. See MEDEL letter to the President of the EU Commission and to the EU Commissioner of Justice about the CVM report on Bulgaria and Romania, 18 December 2018, https://medelnet.eu/index.php/news/europe/483-medel-letter-to-the-president-of-the-eu-commissionand-to-the-eu-commissioner-of-justice-about-the-cvm-report-on-bulgaria-and-romania.

${ }^{11}$ See, for instance, D Kochenov \& P Bárd, The Last Soldier Standing? Courts vs Politicians and the Rule of Law Crisis in the New Member States of the European Union, University of Groningen Faculty of Law Research Paper Series No. 5/2019 (2019); T G Daly, Democratic Decay: Conceptualising an Emerging Research Field, Hague Journal on the Rule of Law (2019); L Louwerse \& E Kassoti, Revisiting the European Commission's Approach Towards the Rule of Law in Enlargement, Hague Journal on the Rule of Law (2019); G Halmai, The Possibility and Desirability of Rule of Law Conditionality, Hague Journal on the Rule of Law (2018); K L Scheppelle, Autocratic Legalism, 85 University of Chicago Law Review 545 (2018); L Pech \& K L Scheppelle, Illiberalism Within: Rule of Law Backsliding in the EU, 19 Cambridge Yearbook of European Legal Studies 3 (2017); D Kochenov \& L Pech, Monitoring and Enforcement of the Rule of Law in the EU: Rhetoric and Reality, 11 (3) European Constitutional Law Review 512 (2015). 
of law crises in Poland and in Hungary in a timely and adequate manner, ${ }^{12}$ and the Commission's proposal to monitor the rule of law in all Member States. The question also seems relevant considering the findings quoted in the 2019 EU Justice Scoreboard - 58\% of Bulgarians perceive judicial independence in the country as 'very bad' or 'fairly bad', which makes Bulgaria the third most pessimistic Member State about court independence after Croatia and Slovakia. ${ }^{13}$

After examining the origin and goals of the CVM, this article explores its drawbacks, as they emerge from the Bulgarian context. On the one hand, the Commission seems to have been lenient about longstanding issues of Bulgaria's justice system, which are within the scope of monitoring, and about incidents evidencing rule of law decline, which are publicly known, such as the harassment of judges. On the other hand, by pretending to comply with the Commission's recommendations under the CVM, Bulgaria deliberately implemented policies compromising its rule of law, which the Commission verified as progress. The article then ponders what lessons may be learned from Bulgaria's case on an EU level in view of the goal to strengthen the rule of law in all Member States. ${ }^{14}$

\section{ORIGIN OF THE CVM: PRE-ACCESSION CONDITIONALITY}

It has been argued that the principle of pre-accession conditionality 'revolutionalised EU enlargement law'. ${ }^{15}$ It emerged from the fifth wave of enlargement when, for the first time, former-communist countries joined the EU. ${ }^{16}$ The principle transformed the accession process from purely political to politico-legal because it made the benefits of EU membership an 'incentive' to conform with the accession criteria. ${ }^{17}$ Nevertheless, it has been contended that 'the application of the principle of pre-accession conditionality was marked by resounding failure, if it was applied at all'. ${ }^{18}$ Although this conclusion seems

\footnotetext{
12 See, for instance, L Pech and K L Scheppelle, n. 11 above, at 46. See also R Uitz, Guest Editorial: The Perils of Defending the Rule of Law through Dialogue, 15 European Constitutional Law Review 1 (2019), D Kelemen \& L Pech, Of Red Lines and Red Herring: The EPP's Delusions about Restraining Orbán (2019), https://verfassungsblog.de/of-red-lines-and-red-herring-the-epps-delusions-about-restraining-orban/. 132019 EU Justice Scoreboard, p 44; The Commission itself stated that the Justice Scoreboard 'enabl[es] to make a deeper analysis based on the national legal and institutional context', COM(2019) 163 final, at 5 . ${ }^{14}$ See the Commission's Communication on 'Further strengthening the Rule of Law within the Union: State of play and possible next steps', $\operatorname{COM(2019)163~final~and~Communication~on~'Strengthening~the~rule~of~law~}$ within the Union: A blueprint for action' COM(2019) 343 final; See also European Parliament Resolution of 14 November 2018 'on the need for a comprehensive EU mechanism for the protection of democracy, the rule of law and fundamental rights' (2018/2886(RSP)).

$15 \mathrm{D}$ Kochenov, EU Enlargement and the Failure of Conditionality. Pre-accession Conditionality in the Fields of Democracy and the Rule of Law 50 (Kluwer Law International, 2008).

16 Estonia, Latvia, Lithuania, Poland, the Czech Republic, Hungary, Slovakia, Slovenia, Cyprus and Malta joined the EU on 1 May 2004.

${ }_{17}$ F Schimmelfennig, EU Political Accession Conditionality after the 2004 Enlargement: Consistency and Effectiveness, 15 (6) Journal of European Public Policy 918-37 (2008).

18 Kochenov, n. 15 above, at 300.
} 
harsh, the cases of Bulgaria and Romania illustrate how political compromises undermine the principle.

Bulgaria and Romania began their accession negotiations with the EU in 2000, but their journey was 'bumpier' compared to the journey of those from the fifth round of enlargement. ${ }^{19}$ Scholars underline that the negotiations with the two countries reflected 'the growing application of differentiated and targeted conditionality'. ${ }^{20}$ While this may be taken as a positive development because EU institutions were sensitive to the specific challenges faced by each candidate State, it may also be interpreted as a sign of fear that these countries were simply not ready for membership. This fear haunted EU institutions even after the end of the negotiation process.

Unlike the accession negotiations with other former-communist countries, the accession talks with Bulgaria and Romania did not go smoothly. The Copenhagen European Council in 2002 decoupled Bulgaria and Romania from the other States in accession talks over concerns for their lack of preparedness, thus postponing their accession. The Presidency conclusions explicitly stress:

It is essential that Bulgaria and Romania seize this opportunity by stepping up their preparation, including fulfilling and implementing the commitments undertaken in the accession negotiations. In this context, the Union underlines the importance of judicial and administrative reform that will help bring forward Bulgaria and Romania's overall preparation for membership. ${ }^{21}$

As these concerns remained until the end of accession negotiations, the Commission included unprecedented safeguard clauses in Bulgaria and Romania's Accession Treaty. ${ }^{22}$ Article 39, termed the 'super-safeguard' clause, ${ }^{23}$ even allowed the Commission to further delay accession if there [was] clear evidence that the state of preparations for adoption and implementation of the acquis in Bulgaria or Romania [was] such that there [was] a serious risk of either of those States being manifestly unprepared to meet the requirements of membership by the date of accession of 1 January 2007'.

Moreover, it has been observed that in the case of Bulgaria and Romania, the Commission broadened the scope of Regular Reports during accession negotiations and underlined the importance of monitoring. ${ }^{24}$ The last monitoring report before these countries joined the EU is particularly revealing of the Commissions' anxieties. ${ }^{25}$ The report set six benchmarks for Bulgaria and four benchmarks for Romania, which became the basis of the CVM benchmarks mentioned in the introduction of this article.

\footnotetext{
19 E Gateva, European Union Enlargement Conditionality 86 (Palgrave MacMillan, 2015).

$20 \mathrm{Ibid}$, at 93.

${ }^{21}$ Conclusions of the Copenhagen European Council, 15917/o2, para 15 (emphasis mine).

${ }_{22}$ See Articles 37-39 of the Accession Treaty.

${ }_{23}$ See Simon Bulmer and Christian Lequesne (eds), The Member States of the European Union (2nd edn, Oxford University Press 2013), at 240.

24 Gateva, n. 19 above, at 93.

$25 \operatorname{COM}(2006) 549$ final.
} 
Despite the limited progress, a year after Bulgaria and Romania's accession, the Commission preferred the carrot to the stick. The July 2008 reports on Bulgaria and Romania under the CVM contain identical sentences:

The Commission considers support to be more effective than sanctions and will not invoke now the safeguard provisions set out in the Accession Treaty. The continuation of the $[\mathrm{CVM}]$ will be needed for some time. ${ }^{26}$

It is also interesting that despite the challenges faced by Bulgaria and Romania, the European Parliament voted by an overwhelming majority to admit them in April 2005. 27 Examining the debates at the European Parliament of 12 April 2005 shows that notable leaders supported these countries' membership and focused on the progress made during the accession negotiations rather than on the vital work that remained to be done. ${ }^{28}$ One can only make conjectures about why the political mood was that elated. One may suspect that the 'Kosovo card' played a key role in triggering the negotiations with Bulgaria and Romania. ${ }^{29}$ The period between 2002-2005 also saw eagerness for the Nabucco Pipeline, which was supposed to pass through Bulgaria and Romania, so these countries were of strategic importance for some Member States committed to the project.

\section{3}

\section{CONCEPTUAL CLARIFICATIONS}

Before examining the Commission's omissions in the monitoring and the specific ways in which Bulgaria's government misused the CVM, it is essential to make some theoretical clarifications. It has been asserted that the recent plethora of literature on democratic decay has resulted into a conceptual 'bazaar' with 'offerings [whose] sheer variety and number [challenge] the possibility of an easy selection of a dominant framework to

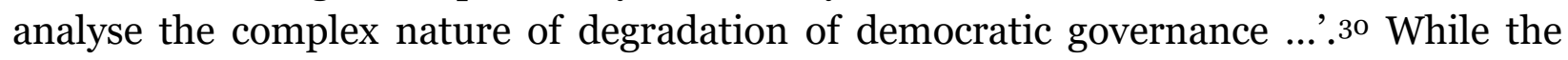
choice of framework is difficult, we argue there are two concepts, which are particularly helpful to understand the developments in Bulgaria vis-à-vis the CVM - post-accession hooliganism and autocratic legalism.

${ }^{26} \operatorname{COM}(2008) 494$ and $\operatorname{COM}(2008) 495$; Emphasis mine.

27 The decision was harshly criticized by some commentators, How Fit Are Romania and Bulgaria for the EU? (2005),

http://www.spiegel.de/international/spiegel/europe-union-how-fit-are-romania-and-bulgaria-for-theeu-a-352874.html.

28 P6_CRE(2005)04-12 (27).

29 Bulgaria and Romania provided 'unconditional assistance to NATO during the Kosovo crisis that produced the political will in the West for beginning serious accession talks'. See S Katsikas, Bulgaria and Romania at Europe's Edge, 113 Current History 118 (2014).

30 Daly, n. 11 above. 
Venelin Ganev has developed the notion of 'post-accession hooliganism' on the basis of Romania's and Bulgaria's immediate post-accession conduct. ${ }^{11}$ Two of the dimensions of this type of hooliganism are 'legislative and behavioral changes that undermined previously stable normative frameworks' and 'a reversal of a general tendency toward stabilization of the interactive patterns and administrative routines known as "state building"'.32 Ganev has observed that the 'negative developments' he has identified in Bulgaria and Romania 'did not occur as a result of an influx of new political players, but because of the altered behavior of already entrenched elites'.33 Prior to joining the EU, Bulgaria and Romania had an incentive to comply with the Commission's recommendations, so that they could be admitted to the Union. However, after 2007, political elites 'did what they wanted'.34 Below we will see that the same conclusion can be drawn based on the CVM. Bulgaria still has not complied with some recommendations, which were made relatively early on. Meanwhile, by pretending to comply with some recommendations, Bulgaria has deliberately compromised its rule of law.

In parallel, it has been stressed that one recognizes an 'autocratic legalist' when 'a democratically elected leader ... launches a concerted and sustained attack on institutions whose job it is to check his actions or on rules that hold him to account, even when he does so in the name of his democratic mandate'. 35 Similarly, 'a constitutional capture' has been defined as 'a scenario where one set of partisan actors tries to obtain control of the political system as a whole (as well as parts of the economy, the media and civil society), rendering subsequent changes in political control virtually impossible'. ${ }^{6}$ The concept of 'rule of law backsliding' seems to resonate a similar idea: 'the process through which elected public authorities deliberately implement governmental blueprints which aim to systematically weaken, annihilate or capture internal checks on power with the view of dismantling the liberal democratic state and entrenching the long-term rule of the dominant party'.37

At the same time, authors have contended that the recent rule of law challenges in Hungary and Poland are different from the threats to the rule of law in other Member States. Pech and Scheppelle maintain:

The existence of significant rule of law problems in EU Member States with historically weak or corrupt judiciaries or countries facing major budgetary cuts cannot be denied. We believe, however, that Hungary and Poland raise challenges of an utterly different nature because rule of law backsliding is a deliberate strategy

\footnotetext{
${ }^{31}$ V I Ganev, Post-Accession Hooliganism: Democratic Governance in Bulgaria and Romania after 2007, 27 (1) East European Politics and Societies and Cultures 26-44 (2013).

$32 \mathrm{Ibid}$, at 27.

$33 \mathrm{Ibid}$, at 40 .

34 Ibid.

35 Scheppelle, Autocratic Legalism, n. 11 above, at 549.

${ }^{36} \mathrm{~J}-\mathrm{W}$ Müller, Protecting the Rule of Law (and Democracy!) in the EU: The Idea of a Copenhagen Commission in C Closa and D Kochenov (eds), Reinforcing Rule of Law Oversight in the European Union 208 (CUP 2016).

37 Pech \& Scheppelle, Illiberalism Within: Rule of Law Backsliding in the EU, n. 11 above, at 10.
} 
pursued by public authorities with the goals of fundamentally undermining pluralism and creating a de facto one-party state ... These are states in which the rule of law had in fact been achieved and is now being systematically dismantled, which is a different sort of problem from not being able to achieve the rule of law in the first place. Backsliding implies that a country was once better, and then regressed. 38

Likewise, Müller has underscored that a 'constitutional capture is different from pervasive corruption (a major problem still in Bulgaria and Romania, for instance)'.39

As evidenced by the fact they were placed under the CVM, Bulgaria and Romania had not achieved the rule of law when they joined the EU. Both are notorious for their corruption, too. $4^{\circ}$ However, this does not mean that their governments are not pursuing deliberate strategies aimed at weakening existing institutions or consolidating power in the hands of one person and his entourage to ensure political change is difficult or even impossible. For the past ten years, Bulgaria has largely been governed by Boyko Borissov, leader of the GERB Party (Citizens for the European Development of Bulgaria), which is a member of the European People's Party (EPP). Borissov currently leads his third government. ${ }^{41}$ We will see that current threats to the rule of law in Bulgaria are comparable to disturbing developments in Hungary and Poland, which became the source of global concern, and triggered a response by EU institutions.

If there is an important difference between the rule of law crises in Poland and Hungary, on the one hand, and Bulgaria's case, on the other, it lies in the CVM itself. As it will be argued, the Commission seems to have underestimated a key structural problem of Bulgaria's justice system. Meanwhile, it has verified as progress pseudo reforms, which preserve the existing state of affairs, as well as reforms promoting autocratic values. Some reforms entailed amendments to the Constitution itself while other reforms 'curb[ed] ordinary laws' in violation of the Constitution - a phenomenon which was observed in Poland.42 In other words, Bulgaria's rule of law declined under the close monitoring and guidance of the Commission.

Before we delve into Bulgaria's CVM, it is worth mentioning that scholars have singled out the sequence of steps which autocratic leaders often take to consolidate power and remove checks and balances - capturing the electoral system, the media, the

\footnotetext{
$3^{8}$ Ibid, 11-12.

39 J-W Müller, Rising to the Challenge of Constitutional Capture: Protecting the Rule of Law within EU Member States (2014), https://www.eurozine.com/rising-to-the-challenge-of-constitutional-capture/. $4^{\circ}$ According to the latest 2018 Corruption Perceptions Index by Transparency International, Bulgaria is the most corrupt EU member (77th in the world), Hungary is the second most corrupt EU member (64th in the world) and Romania is the third most corrupt EU member (61st in the world), https://www.transparency.org/cpi2018.

${ }^{41}$ Borissov's first government (2009 - 2013); Borissov's second government (2014 - 2016); Borissov's third government (2017 - present).

42 Kochenov \& Bárd, The Last Soldier Standing? Courts vs Politicians and the Rule of Law Crisis in the New Member States of the European Union, n. 11 above, at 10.
} 
judiciary, etc. 43 It has been contended that the two states which 'satisfy these definitional elements' are Hungary and Poland. 44 While in the next section we focus on threats to the rule of law which are within the scope of CVM benchmarks, one should keep in mind that Bulgaria seems to have completed other steps from this autocratic playbook. 45

The main logic underlying the CVM is dialogue between the Member State in question and the Commission, which is evidenced by regular CVM reports. In each report, the Commission assesses progress and makes concrete recommendations. In subsequent reports, it verifies if further progress has been achieved and makes new recommendations if necessary. Each report under the CVM is divided into two - the main 'political' report and the 'technical' report which is more detailed.

In this section, we pay close attention to three structural and systemic threats to the rule of law in Bulgaria which are related, and which have not been adequately addressed by the CVM. It will be argued that one of the key challenges, which Bulgaria had not solved before acceding to the EU, was the untouchable and unaccountable Prosecutor's Office with excessive powers which could be misused for political aims because it was politically dependent and overshadowed the courts. Nevertheless, not only the Commission did not manage to help Bulgaria find a proper solution through the CVM, but also through CVM assessment and recommendations it either helped Bulgaria's government to preserve the existing problems or to exacerbate them. In parallel, the Commission seems to have turned a blind eye to threats to the rule of law which are publicly known and within the scope of monitoring - namely, intimidation of judges who refuse to succumb to political orders, including orders by Bulgaria's Prosecutor's Office. This seems to confirm prior concerns for dual standards in enforcing EU values stipulated in Article 2 of the Treaty on European Union (TEU). 46

\footnotetext{
43 See Pech \& Scheppelle, Illiberalism Within: Rule of Law Backsliding in the EU, n. 11 above, 9-10. 44 Kochenov \& Bárd, The Last Soldier Standing? Courts vs Politicians and the Rule of Law Crisis in the New Member States of the European Union, n. 11 above, at 8.

45 For instance, the NGO Reporters Without Borders have established that $80 \%$ of media is owned by one person. See https://rsf.org/en/bulgaria. When Bulgaria joined the EU in 2007, it ranked 51st in the world in the Press Freedom Index by Reporters Without Borders. In 2019, it was ranked 111th; Special Eurobarometer 477 showed that $72 \%$ of Bulgarians worry that the election results are manipulated (contrast with the $56 \%$ EU average) and $81 \%$ of Bulgarians fear that votes are being bought or sold (contrast with the $55 \%$ EU average).

46 Scholars had noted that in the case of Poland, 'European institutions ... started to react far more determinedly than in the Hungarian case', A von Bogdandy, P Bogdanowicz, I Canor, M Taborowski \& M Schmidt, Guest Editorial: A Potential Constitutional Moment for the European Rule of Law - The Importance of Red Lines, 55 Common Law Market Review, 984 (2018).
} 


\subsection{OMNIPOTENT AND UNACCOUNTABLE PROSECUTOR'S OFFICE}

One of the systemic threats to the rule of law in Bulgaria's justice system is the untouchable status of Bulgaria's General Prosecutor coupled with the vertical, Soviet structure of Bulgaria's Prosecutor's Office where all decisions depend on him and where there are no checks and balances.47 The General Prosecutor has a 7-year term. After providing background on why this is a key challenge for Bulgaria, this section considers how the Commission seems to have contributed to the problem via the CVM by helping the General Prosecutor consolidate more power.

Meanwhile, it should be noted that one of the main reasons why the Venice Commission was troubled with regard to the reform of the Prosecutor's Office in Poland was the new extensive powers of the Prosecutor General to intervene in individual cases and to overturn decisions by subordinate prosecutors without safeguards 48 - essentially, the same problems which Bulgaria faces.

\section{1[a] Background}

The current model of the prosecution was introduced to Bulgaria during the constitutional reform in 1947 after Bulgaria became a communist country. Following the end of communism, Bulgaria did not implement any substantial reforms in this institution.49 The President of the Venice Commission has argued publicly: 'The Soviet model of [Bulgaria's] prosecution must be decisively turned down. It turns it into a source of corruption and blackmail and creates opportunities for its use for political aims'.50

Some of the consequences of this model for ordinary citizens can be seen in the Annual Reports of the European Court of Human Rights (ECtHR). The latest one shows that since ratifying the European Convention on Human Rights (ECHR) in 1992, Bulgaria has been found in violation of Article 5 (right to liberty and security) 270 times and Article 6 (right to a fair trial) 291 times. ${ }^{11}$ The ECtHR has discussed the structure and the powers of Bulgaria's prosecution in Kolevi $v$ Bulgaria (2009). $5^{2}$ Specifically, the ECtHR found as 'plausible' the applicants' assertion that

given the centralised structure of the Bulgarian prosecution system, based on subordination, its exclusive power to bring charges and the procedural and

47 Prescribed by Articles 126 and 127 of Bulgaria's Constitution; See also Chapter 6 of the Law on the Judiciary.

48 Opinion 892/2017 CDL(2017)037 of the Venice Commission, para 90.

49 A 2009 opinion by the Venice Commission on Bulgaria's reforms of the Law on the Judiciary notes that 'the prosecutors retain elements of powers typically found in the traditional Soviet-style prokuratura model'. Opinion no. 515/2009, 16 March 2009, at 3.

50 ‘Delayed EU Audit of Bulgaria Prosecution Raises Concern' (2016)

https://balkaninsight.com/2016/05/31/postponed-eu-monitoring-of-bulgaria-s-prosecution-worriesexperts-05-31-2016/.

${ }^{51} 2018$ Annual Report of the European Court of Human Rights, at 178.

${ }^{2}$ Application no. 1108/02, 5 November 2009. 
institutional rules allowing full control by the Chief Public Prosecutor over every investigation in the country ... it was practically impossible to conduct an independent investigation into circumstances implicating him ...53

The Court also observed that

as a result of the hierarchical structure of the prosecution system and, apparently, its internal working methods, no prosecutor would issue a decision bringing charges against the Chief Public Prosecutor. This appears to have been due to the fact that the Chief Public Prosecutor and high-ranking prosecutors have the power to set aside any such decision taken by a subordinate prosecutor or investigator. As a result, it is still the case that the Chief Public Prosecutor cannot be temporarily suspended from duty against his will, as that can only be done if charges have been brought against him. 54

The facts of Kolevi may showcase why the structure and powers of the Prosecutor's Office are problematic. Prosecutor Kolev was concerned that Prosecutor Filchev who served as Bulgaria's General Prosecutor until 2006 was mentally ill and acted unlawfully, including fabricating charges to open bogus criminal proceedings against others. $55 \mathrm{He}$ made his concerns public by sending letters to various institutions. ${ }^{6}$ Subsequently, the Prosecutor's Office opened a series of criminal proceedings against Kolev and members of his family.57 In May 2001, prosecutor Kolev allegedly learned of a plan by the Prosecutor's Office to plant drugs on him, so that he could be arrested: he wrote to the Minister of Interior and the Supreme Judicial Council and gave interviews to the press. 58 In June 2001, Kolev was indeed arrested and Bulgarian authorities claimed to have found drugs in his pockets and in his car.59 The Prosecutor's Office demanded his permanent pre-trial detention and the Sofia City Court granted it. ${ }^{60}$ After a long legal battle, which reached the highest instance, the Supreme Court of Cassation ruled the proceedings against Kolev were 'inadmissible from the outset'. ${ }^{61}$

Prosecutor Kolev submitted an application to the ECtHR and sent letters to institutions to inform them he feared for his life in December 2001. 62 In December 2002, Kolev was brutally murdered in front of his home. ${ }^{63} \mathrm{Kolev}$ had been working on a private inquiry into criminal activities of the General Prosecutor. A senior official from the antiterrorist squad with whom he had discussed his investigation was also murdered two days

\footnotetext{
53 Ibid, para 209.

54 Ibid, para 205.

55 Application no. 1108/02, 5 November 2009, para 14.

${ }^{6} \mathrm{Ibid}$, paras 16-17.

57 Ibid, paras 21-27.

${ }^{8} \mathrm{Ibid}$, paras 28-29.

$59 \mathrm{Ibid}$, para 30.

6о Ibid, paras 36-38.

${ }^{61} \mathrm{Ibid}$, para 49.

62 Ibid, paras 62-63.

$63 \mathrm{Ibid}$, paras 64 and 85 .
} 
after Kolev. ${ }^{64}$ The ECtHR established that Bulgaria violated Article 5 (right to liberty) in light of Kolev's unlawful detention as well as Article 2 (right to life) in light of the subsequent inefficient investigation into Kolev's murder.

Despite reminders to comply with Kolevi by the Committee of Ministers of the Council of Europe twice per year, Bulgaria still has not done so. ${ }^{65}$ In 2017, the Venice Commission concluded:

in the current Bulgarian system there is a weak structure for accountability of the [Prosecutor General] who is essentially immune from criminal prosecution and is virtually irremovable by means of impeachment for other misconduct ...66

Whereas the horror story in Kolevi may appear like an isolated case at first glance, recent public scandals involving the current General Prosecutor Sotir Tsatsarov may shed further light on why the structure of Bulgaria's Prosecutor's Office is a threat to the rule of law. In 2013, shortly after Tsatsarov entered in office, Bulgaria was shaken by a wiretap scandal allegedly evidencing how Tsatsarov was personally elected by Prime Minister Boyko Borissov. ${ }^{67}$ In 2015, the Bulgarian partner of the Organized Crime and Corruption Reporting Project Bivol published wiretaps of conversations between the President of the Sofia City Court and another judge. The controversy is known as Yaneva Gate. 68 The two judges discuss how Prime Minister Boyko Borissov and General Prosecutor Sotir Tsatsarov instruct judges how to decide cases. In 2016, investigator Boyko Atanasov complained publicly there was a special unit in the Prosecutor's Office, which was led by Tsatsarov and 'deal[t] with concealing crimes and tipoffs against people close to the government, and at the same time, use[d] signals and tipoffs to blackmail the inconvenient'.69

These controversies seem to allege lack of separation of powers, lack of judicial independence, and high-level corruption. Given the current legal framework and the General Prosecutor's powers, these serious allegations cannot be objectively investigated and verified.

\footnotetext{
64 Ibid, para 108.

65 See the latest decision by the Committee of Ministers regarding the execution of Kolevi of 14 March 2019: https://search.coe.int/cm/Pages/result details.aspx?ObjectID=09000016809372d5. 66 Opinion No. 855/2016, 9 October 2017, at 9.

${ }_{7}$ Kokinov to Borisov about Tsatsarov: "Do not smile at me. You chose him" (2013), https://www.mediapool.bg/kokinov-kam-borisov-za-tsatsarov-ne-mi-se-podsmihvai-ti-si-go-izbiranews205766.html.

68 Top Judge Calls for Independent Body to Investigate Leaked Tapes in Yaneva Case (2015), http://www.bta.bg/en/c/DF/id/1220434.

69 Bulgaria: Prosecutor General's 'Special Unit' Said to Blackmail Politicians (2016), https://www.occrp.org/en/27-ccwatch/cc-watch-briefs/5006-bulgaria-prosecutor-general-s-special-unitsaid-to-blackmail-politicians.
} 


\section{1[b] The Commission's Monitoring}

The above background is necessary to comprehend how the Commission exacerbated the structural problem through the CVM. The 2011 CVM report is the first to mention the need for a proposal for a reform of Bulgaria's prosecution. ${ }^{70}$ This seems odd because, as explained above, two of the benchmarks Bulgaria had to satisfy from CVM's beginning were related to the fight against corruption and one is related to the fight against organized crime. As early as 2009, the Venice Commission had noted that the structure of the Prosecutor's Office is inappropriate since 'there has long been reported to be a problem with corruption among some prosecutors in Bulgaria'. ${ }^{71}$ A Prosecutor's Office prone to corruption cannot adequately investigate corruption and organized crime.

The 2012 CVM report explicitly refers to Kolevi and stresses:

Bulgaria still has to take measures to strengthen the internal independence of prosecutors in order to ensure independent, objective and effective investigations. In particular, Bulgaria needs to address the absence in Bulgarian law of sufficient guarantees for an independent investigation into offences of which the Chief Public Prosecutor or other high-ranking officials close to him may be suspected.72

Yet, peculiarly one of the recommendations in the same report is: 'New General Prosecutor should have a mandate to reform the prosecution in structure, procedures and organisation on the basis of an independent functional audit and in cooperation with external experts'.73 This is surprising for those acquainted with the Bulgarian context, including the picture emerging from Kolevi. Considering the structure of the Prosecutor's Office and its particularities, it seems unwise to impose the responsibility for managing the reform on the General Prosecutor himself. One may reasonably argue that a prosecutor who benefits from excessive powers does not have an incentive to limit these powers, especially if he was appointed with the political protection of the governing party. On the contrary, the ruling party has an interest in weaponizing the prosecution against the opposition, media, civil society, inconvenient opponents, etc.

The Commission reminded Bulgaria of Kolevi in the latest 2018 CVM report,74 which identified 'significant progress' in the legal framework benchmark because of the reform of Bulgaria's criminal law, which was implemented in $2017^{75}$ and which the Commission had recommended in the January 2017 CVM report. ${ }^{6}$ While it recognized

70 $\operatorname{COM(2011)} 459$ final, at 9; Recommendation 1(a) states: 'Establish proposals for a reform of the Supreme Judicial Council, the Supreme Cassation Prosecution Office and the Prosecution in general regarding structures, legal attributions, composition, appointments and internal organisation'.

${ }^{71}$ Opinion no. 515/2009, 16 March 2009, at 3.

${ }^{72} \mathrm{COM}(2012) 411$ final, p 10, footnote 40; Emphasis mine.

$73 \mathrm{Ibid}$, at 20.

74 Between the 2012 report and the 2018 report, the Commission only brought up Kolevi once in the November 2017 'technical' report associated with the CVM report. See SWD(2017) 700 final, footnote 53.

$75 \operatorname{COM}(2018) 850$ final, $4-5$.

${ }^{76} \operatorname{COM}(2017) 43$ final, at 9. 
that a 'sensitive point' on which there was no conclusive solution 'concern[ed] the procedures in place to hold accountable the most senior positions in the magistracy, including a serving Prosecutor-General, in the event of serious allegations of wrongdoing or criminal acts', the Commission declared the legal framework benchmark provisionally closed. 77

As it can be seen, the Commission dropped the requirement for investigating 'highranking officials close to' the Prosecutor General, which was mentioned in the 2012 report. This is potentially problematic because a serving Prosecutor General appoints close ones at key positions within the prosecution through unilateral internal orders or through his dominance in the Supreme Judicial Council, which is discussed in the next section. Besides, the claim for 'significant progress' in the legal framework merits unpacking. Between 2012 and 2018, not only Bulgaria did not reform the vertical structure of its Prosecutor's Office, but also it increased the prosecution's powers by amending Bulgaria's criminal law upon suggestions by the Prosecutor's Office itself, and in seeming violation of Bulgaria's Constitution and the ECHR.

In older CVM reports, the Commission has praised the General Prosecutor for increasing his own powers through internal changes in the prosecution despite its prior recommendation that changes should be made after an external audit. For example, the 2016 CVM report states: '[t]he prosecutor's office has been pursuing a pragmatic approach to enhancing capacity through organisational changes ... The latest step in this strategy was the establishment ... of a strengthened inter-agency unit attached to the Sofia City Prosecutor's Office dedicated to the investigation and prosecution of high-level corruption. There are indications that this closer cooperation between services in a specialised structure is beginning to make a positive contribution' ${ }^{78}$ While this unit gathers prosecutors, secret service agents, and policemen, it reports to the General Prosecutor.

It is worth mentioning that Hristo Ivanov, Minister of Justice in Borissov's second government, was the only government member who pushed for an external audit of the Prosecutor's Office. As explained below, Ivanov resigned after GERB sabotaged his proposal for a major reform of the Supreme Judicial Council. Eventually such an audit materialized despite Ivanov's resignation. Bulgaria's 2017 CVM report underlines: 'The Bulgarian authorities - with the Prosecutor's Office in the lead and with the support of the Ministry of Justice - have prepared a roadmap containing a number of actions as a follow-up to this analysis'.79 Most of these actions envisaged in the roadmap constitute of amendments to Bulgaria's criminal law, which the Commission praised as progress in the latest 2018 CVM report.

A closer look into these amendments shows that they increase the already excessive powers of the Prosecutor's Office and seem to violate the ECHR - namely Article 6 on the

\footnotetext{
77 Ibid.

${ }_{78} \mathrm{COM}(2016) 40$ final, at 9.

$79 \mathrm{COM}$ (2017) 750 final, at 6; Emphasis mine.
} 
right to a fair trial and Article 13 on the right to an effective remedy - as well as Bulgaria's Constitution. ${ }^{80}$ For instance, in Bulgaria the institution of criminal proceedings and the raising of charges is not subjected to judicial oversight. An accused person may only appeal before the Prosecutor's Office, but, as established in Zvezdev v Bulgaria, this is not an effective remedy given the hierarchical structure of Bulgaria's prosecution. ${ }^{81}$

The 2017 reform praised by the Commission not only did not remedy this problem, but also introduced the concept of the 'eternally accused person'. Until 2017, former Chapter 26, Article 368 of the Code of Criminal Procedure allowed every accused person to ask the court directly to examine their case if the investigation lasted longer than 1 year for minor offences and 2 years for major offences. This option has been removed from the Code of Criminal Procedure as Chapter 26 has been entirely rephrased. In practice, this means that the prosecution can investigate an accused person indefinitely without the latter ever being indicted in court. In other words, the prosecution can accuse someone upon the unilateral decision by the General Prosecutor, so that this person is deprived of rights, but they may never be able to defend themselves in court - the person could be kept in pre-trial detention, they could have their property confiscated, etc. A second example of the repressive arsenal introduced by the reform is that pursuant to the current Article 248(3), a person may contest procedural violations by the prosecution only at the first court hearing following indictment.

\subsection{POLITICAL SUPREME JUDICIAL COUNCIL}

The Supreme Judicial Council (SJC) is the most important body in Bulgaria's justice system because it is responsible for the appointment and promotion of all judges, prosecutors, and investigators as well as the institution of disciplinary proceedings against them. However, this institution is traditionally susceptible to political influence, including the influence of the General Prosecutor, due to its structure. Hristo Ivanov, Minister of Justice in Borissov's second government, had prepared a draft proposal for constitutional reform, which would ensure judicial independence and limit the excessive influence of the General Prosecutor on the SJC.82 However, after Parliament enacted amendments which had little to do with his proposal in December 2015, he resigned. In parallel, judges protested, and the Bulgarian Judges Association published an open letter to Bulgarian citizens. ${ }^{83}$ The letter emphasizes:

\footnotetext{
8o Article 31(3) enshrines the presumption of innocence. Article 31(4) specifies that constraints on the rights of accused people cannot go beyond what is necessary to achieve justice.

${ }^{81}$ Application no 47719/07, 7 January 2010, paras 36-40.

82 Note Borissov's second government was a coalition with the small democratic party 'Reformist Bloc'. Ivanov was appointed from their quota.

83 Open Letter to Bulgarian Citizens by the Bulgarian Judges Association, 14 December 2015, https://www.rechtersvoorrechters.nl/media/bulgarije/OpenLetterBJA.pdf.
} 
It is important to make clear exactly what happened ... and how it affects every single citizen of Bulgaria. The long-awaited changes that were in the draft for constitutional amendment ... were instead replaced with 'accepted corrections' which will not result in a real change; will not give any guarantees for the rule of the law and the independence of judges; and will not eliminate the widely suspected dependencies within the judicial system. The ratio of the quotas of the colleges of judges and prosecutors may mean little to those not familiar with the issue, but it is important, because it gets down to the most fundamental problem - which is whether we can have judicial courts that are independent of politicians and whether we can rely on a prosecutor's office which is independent of political interference.

Despite the concerns of judges, Bulgaria's 2016 CVM report states: 'While these amendments included some significant changes from the text originally proposed by the government, their adoption still represents an important step towards a reform of the SJC'. ${ }^{84}$ The 2018 CVM report made positive observations about the newly elected SJC in 2017, insisted on the need that the SJC demonstrates results, and declared the judicial independence benchmark provisionally closed. 85

\section{2[a] Premature Optimism}

The Commission's optimism can be distinguished from observations by the Council of Europe in 2017 that Bulgaria disregarded recommendations by the Venice Commission while implementing the aforementioned constitutional reform. ${ }^{86}$ The same report by the Council of Europe also identifies 'tendencies to limit the independence of the judiciary made though attempts to politicise the judicial councils and the courts' in Bulgaria, Poland, and Turkey. ${ }^{87}$ In that light, the Commission's appreciation of the Bulgarian reform may be contrasted with its own concerns about the capture of the Polish courts and judicial council, too. 88

The main achievement of the cosmetic constitutional reform in Bulgaria is that it divided the SJC into a prosecutorial and a judicial college. Prior to the reform, the SJC took all decisions as a single structure which meant that prosecutors voted on all key issues of importance for the judiciary. However, the reform has neither ensured judicial independence nor has curtailed the disproportional influence of the General Prosecutor on the SJC. Following the reform, the body has 25 members -11 are elected by Bulgaria's

\footnotetext{
${ }_{84} \mathrm{COM}(2016) 40$ final, at 3.

$85 \operatorname{COM}(2018) 850$ final, $3-4$.

86 'New threats to the rule of law in Council of Europe member States: selected examples', Doc. 14405, 25 September 2017, at 10.

87 Ibid, at 3.

88 Commission's Reasoned Proposal in accordance with Article 7(1) of the Treaty on European Union regarding the rule of law in Poland, $\operatorname{COM}(2017) 835$ final, para 5.
} 
Parliament, 5 by the Prosecutor's Office ( 1 investigator and 4 prosecutors), 6 by the judiciary, and 3 become members automatically (the President of the Supreme Court of Cassation, the President of the Supreme Administrative Court and the General Prosecutor). ${ }^{89}$ The prosecutorial college comprises the General Prosecutor, 4 prosecutors and 1 investigator, and 5 members from the political quota. $9^{\circ}$ The judicial college includes the other 14 members of the SJC. 91

Those acquainted with the Bulgarian context may immediately identify red flags just based on the body's structure. It is visible that the General Prosecutor controls at least six of the 11 votes in the prosecutorial college - his own as well as the votes of the prosecutors and the investigator. This is because they are his direct subordinates. As explained above, Bulgaria's Prosecutor's Office has an entirely vertical structure, known as a Soviet structure, where all decisions depend on the General Prosecutor. The General Prosecutor's dominance in the college results in his direct control over the appointment and promotion of prosecutors as well as the initiation of disciplinary proceedings against prosecutors and investigators. ${ }^{2}$ It also means that nobody, in practice, monitors the work of the General Prosecutor. The unhealthy balance in this college can be seen in the 2018 appointment of the Deputy General Prosecutor Ivan Geshev - he was the only nominee, he was nominated by the current General Prosecutor Sotir Tsatsarov, nobody asked any questions, and the vote was unanimous. 93 It is also illustrated by Geshev's nomination for General Prosecutor in 2019 - Geshev's candidacy was put forward by the current General Prosecutor Tsatsarov and supported by all members of SJC's prosecutorial college. 94 In that light, it may be helpful to remember that a key criticism by the Venice Commission regarding the Polish reform of the Public Prosecutor's Office was that the National Council of Public Prosecutors was incapable of ensuring prosecutorial independence. 95 Bulgaria's case is not substantially different.

\section{2[b] Political Dependencies}

A second red flag in SJC's structure is the so-called political quota - 11 members are directly elected by Bulgaria's National Assembly. They are, in fact, appointed by the governing majority. Hence, there is a distinct possibility that they would be elected only if they have the government likability factor and despite professional shortcomings. This allows for political interference in decisions by the SJC.

\footnotetext{
89 Amended Article 130 of Bulgaria's Constitution.

90 New Article 130a(4) of Bulgaria's Constitution.

${ }^{91}$ New Article 130a(3) of Bulgaria's Constitution.

92 New Article 130a(5) of Bulgaria's Constitution; Article 30(5) of the Law on the Judiciary which was amended in 2016.

93 Verbatim Report No. 19 of the Sitting of SJC's Prosecutorial College on 4 July 2018.

94 Extraordinary Sitting of SJC's Prosecutorial College on 22 July 2019. The Verbatim Report is not public at the time of writing of this article.

95 Opinion 892/2017 CDL(2017)037 of the Venice Commission, paras 92-99.
} 
The judicial and the prosecutorial college form what is known as SJC's Plenum, which takes key decisions for Bulgaria's justice system. Pursuant to Article 129(2) of Bulgaria's Constitution, which was amended in the above-mentioned reform, the President of the Supreme Court of Cassation, the President of the Supreme Administrative Court and the General Prosecutor are appointed by the President upon a proposal by SJC's Plenum. The role of the President is purely symbolic as the same Article explicitly states that he cannot refuse appointment if the Plenum makes the same proposal for the second time. This means that the election of the two highest-ranking judges in Bulgaria depends on the prosecutors and the political quota - as explained above, only 8 of the 25 SJC members are judges. In parallel, the election of a future General Prosecutor depends on the will of the current General Prosecutor and the political quota. This aspect should be considered in light of the deficiencies identified in Kolevi not only a current General Prosecutor cannot be investigated, but also a former one would most likely not be investigated because he has blessed his heir. Beyond appointments, the Plenum takes decisions on the remuneration of judges, comments on legislative proposals by Parliament, etc. ${ }^{96}$

A concrete example, which raises concern about the political dependencies of the SJC, is the vote on the suspension of the Polish National Judicial Council (KRS) from the European Network of Councils for the Judiciary (ENCJ) due to concerns for lack of judicial independence. Bulgaria's SJC discussed its position on the matter on 13 September 2018. As visible from the verbatim report of the sitting, Boyan Magdalinchev, who was elected from the political quota and subsequently appointed as the Representative of the SJC, asked the Ministry of Foreign Affairs as well as the Ministry of Justice about their opinion on KRS's suspension. 97 This is surprising because Article $117(2)$ of Bulgaria's Constitution explicitly says that judicial authorities are independent of the executive and that judges, jurors, prosecutors, and investigators are bound only by the law. It is also unclear on what legal grounds such advice was sought. Despite this, both Ministries recommended in writing that suspending the KRS was not advisable. The vote itself is also quite revealing - out of the $18 \mathrm{SJC}$ members who were present, 4 voted for suspension, 1 voted against suspension, and 13 abstained. ${ }^{8}$ All present members of the prosecutorial college abstained; out of the 8 present members of the political quota, 7 abstained and 1 voted against the suspension of the KRS.99 Bulgaria's delegation was among the few that abstained at the General Assembly of the ENJC. ${ }^{100}$

\footnotetext{
${ }^{96}$ On the mandate of the Plenum, see Article 30 of the Law on the Judiciary, amended in 2016.

97 Verbatim Report No. 22 of the Sitting of SJC's Plenum on 13 September 2018.

98 Ibid.

99 Ibid.

${ }^{100}$ It was reported that there were 100 votes for suspension, 6 votes against suspension, and 9 abstaining votes, The ENCJ suspends the membership of the new Polish Judiciary Council (2018), https://www.tvn24.pl/tvn24-news-in-english,157,m/the-encj-suspends-the-membership-of-the-newpolish-judiciary-council,869098.html.
} 
Finally, the political quota seems to lead to dysfunctionality and political decisions within the judicial college too. The 2018 election of the President of the Sofia City Court is especially revealing. There were two candidates - Alexey Trifonov received 9 votes while Evgeni Georgiev received 4 votes. ${ }^{101}$ Prior to this election, the General Assembly of the Sofia City Court held an internal election to nominate a candidate. This is possible pursuant to 2016 amendments to the Law on the Judiciary, which are supposed to promote judicial independence. ${ }^{102}$ At this internal election, Georgiev received 56 votes while Trifonov received 25 votes. ${ }^{103}$ In other words, the SJC judicial college ignored the will of the majority of judges at the Sofia City Court. Following the appointment of Trifonov, the three Vice-Presidents of the Sofia City Court deposited their resignations as a sign of protest.

\subsection{COURT CAPTURE}

In this section, we argue that the CVM has not managed to address the government's progressive capture of the courts. One aspect of the capture is the pseudo reform of the SJC discussed above. However, there are developments, which are specific to the Bulgarian context. On the one hand, the government pressures judges through behind the curtain or overt criminal means - publicly available information which has not been adequately addressed by the Commission. On the other hand, the Commission seems to have encouraged the court capture by advising the government to create a system of parallel courts, which are, in practice, dominated by the Prosecutor's Office.

\section{3[a] Pressure}

Yaneva Gate, which we mentioned in the section on the omnipotence of the General Prosecutor, seems pivotal in understanding the behind the curtain relationship between courts, on the one hand, and prosecutors and politicians, on the other hand. In 2015, Bivol, an investigative media, published leaked recordings of conversations between the President of the Sofia City Court Vladimira Yaneva and another judge. ${ }^{104}$ The judges discussed at length how Prime Minister Borissov, other politicians, and General Prosecutor Tsatsarov instruct them how to decide cases and what orders to hand down, how they sign authorizations for surveillance and wiretapping without reading the case materials, etc. The scandal was so big that the Commission could not ignore it - it is mentioned in Bulgaria's 2016 CVM report. The report contains the following recommendation:

\footnotetext{
${ }^{101}$ Verbatim Report of the Prosecutorial College No. 37 of 27 November 2018.

${ }_{102}$ Article 85(3) of the Law on the Judiciary.

103 Verbatim Report of the Prosecutorial College No. 37 of 27 November 2018, at 111.

104 Recordings are available on www.bivol.bg.
} 
Provide the conditions for an impartial investigation into the different allegations of high level corruption within the Sofia City Court, in particular with regard to possible systemic implications, including possible comparable practices in other courts. ${ }^{105}$

While footnote 27 of the technical report specifies:

While it is not the role of the Commission to enter into discussions on how Member States should organise independent investigations into individual alleged cases, the benchmark entails that, as part of its monitoring work, the Commission should report on Bulgaria's efforts to follow up on such allegations. ${ }^{106}$

These comments and recommendations seem to indicate the Commission has not grasped the essence of the problem. Considering the structure of Bulgaria's Prosecutor's Office, it is practically impossible to investigate these facts as the General Prosecutor is implicated - an issue the Commission was aware of because of Kolevi. The SJC, which, as clarified above, is susceptible to political influence, is not capable of inquiring into the facts either. Moreover, if judges decide cases based on the whims of the Prime Minister and the General Prosecutor, one does not need to establish if there are such practices in other courts: these are serious allegations, which, if proven, are sufficient for the criminal prosecution of both the Prime Minister and the General Prosecutor. Since the CVM comments and recommendations are addressed at the government, it does not seem realistic that Borissov's own government would ensure an independent investigation into facts which, if proven to be true, would incriminate Borissov and force the government to resign.

Besides, it appears the Commission has not realized why the Sofia City Court is hugely important by virtue of its jurisdiction. Namely, it has competence to authorize surveillance and wiretapping in Sofia which is the capital of the business and political life of the country. ${ }^{107}$ If judges authorize the use of such means without reading the case materials, as it emerges from the Yaneva Gate tapes, they facilitate prosecutorial arbitrariness, unjustified invasion of privacy, opportunities for blackmail of the opposition, etc. Finally, although Bulgaria did not carry out an investigation into the facts, the Commission was not troubled in subsequent CVM reports.

A second example of a controversy to which the CVM did not react in an adequate manner is the case of the President of the Supreme Court of Cassation Lozan Panov. The highest-ranking judge in Bulgaria is outspoken about the harassment to which he has been subjected for years because, in his words, he refuses to comply with political orders and orders by the General Prosecutor. ${ }^{108}$ Some of the intimidatory tactics were visible to

$105 \mathrm{COM}(2016) 40$ final; Yaneva Gate is one of several corruption scandals involving this court.

$106 \operatorname{SWD}(2016) 15$ final.

${ }^{107}$ Article 15 of the Law on Special Intelligence Means.

${ }_{108} \mathrm{R}$ Vassileva, The Disheartening Speech by the President of Bulgaria's Supreme Court Which Nobody in Brussels Noticed (2018), https://verfassungsblog.de/the-disheartening-speech-by-the-president-ofbulgarias-supreme-court-which-nobody-in-brussels-noticed/. 
the general public, as they were reported in the media. In 2017, the car bolts of his official state car were found to be loosened, but the Prosecutor's Office refused to investigate because it deemed the bolts loosened by themselves. The producer of the car, Mercedes, publicly declared this was impossible from an engineering perspective, but no further action was taken. ${ }^{109}$ In 2017, masked men recreated a dreadful scene from The Godfather when Panov was entering the SJC building. ${ }^{110}$ The CVM reports which were published after these incidents and Panov's public complaints ignore these worrisome developments. After the Commission provisionally closed the judicial independence benchmark in the 2018 report, Magistrats Européens pour la Démocratie et les Libertés (MEDEL) sent a letter to the Commission in which it protested the conclusions and asked the Commission to 'urgently give full and close attention to the particular situation of Justice Lozan Panov, President of the Supreme Court of Cassation of Bulgaria'. ${ }^{111}$

\section{3[b] Parallel Court System}

Bulgaria has formally complied with some early recommendations in the CVM reports only to undermine them. Meanwhile, the Commission may not have realized the damage it has encouraged.

The July 2009 CVM report recommends Bulgaria to 'set up specialised structures for prosecuting and judging high level corruption and organised crime cases with appropriate functional and political independence'. ${ }^{112}$ Borissov's first government pushed for amendments in the Law on the Judiciary to create the Specialized Criminal Court, which serves both as a first instance and as a second instance of appeal and which is mirrored in a Specialized Prosecutor's Office, part of the Prosecutor's Office. Despite criticism by judges, politicians from the opposition, and human rights activists that there was a high risk of violations of fundamental rights, ${ }^{113}$ Parliament amended the law in 2011. This peculiar institution was modelled after the Criminal Chamber of Audiencia Nacional in Spain. ${ }^{114}$

It has been asserted that ' $[\mathrm{t}] \mathrm{he}$ preceding account of the pre- and post-enactment legislative history of [the specialized courts] illustrates the limited involvement of members of the judiciary and members of civil society as a whole in reforming the

109 The Prosecution Blamed Mercedes for the Loosened Bolts of Panov's Car (2017), https://www.capital.bg/politika i ikonomika/bulgaria/2017/06/19/2992169 prokuraturata obvini me rcedes za razvitite boltove na/.

${ }^{110}$ Lozan Panov Suspects He May Be Physically Liquidated (2017),

https://www.capital.bg/kakvo_stava/2017/05/05/2966069 lozan panov dopusna che moje da bud e otstranen.

${ }_{111}$ MEDEL letter, n. 10 above.

${ }_{112} \operatorname{COM}(2009) 402$ final, at 7.

${ }^{113}$ For an overview of the debates on this institution, see Y Kuzmova, The Bulgarian Specialized Criminal Court after One Year: A Misplaced Transplant, an Instrument of Justice, or a Tool of Executive Power?, 32 Boston University International Law Journal 245-61 (2014).

$114 \mathrm{Ibid}$, at 241. 
judiciary' which 'goes against the aspirations of the CVM, and illustrates the perverse logic used by leaders of the parliamentary majority in spearheading institutional reform within the judiciary'. ${ }^{115}$ It has also been stressed that the '[Specialized Criminal Court] phenomenon treats the court and its accouterments as a full-fledged EU transplant without the necessary predicates in the institutional and legal structure of the Bulgarian judiciary'. ${ }^{116}$ The latter observation is key to understanding what went wrong. This structure, which currently has exclusive competence for corruption and organized crime, was set up before a substantive reform of the Prosecutor's Office and the SJC. This, however, does not seem to have troubled the Commission. In subsequent CVM reports, the Commission insisted that Bulgaria show a 'track record' of convictions for corruption and organized crime. ${ }^{117}$

One of the high-profile cases, which resulted in a conviction in 2019, may illustrate how the track record Bulgaria is building does not seem to evidence respect for the rule of law. In April 2018, the Specialized Prosecutor's Office in collaboration with the newly developed Anti-Corruption Agency arrested the mayor and deputy mayor of Mladost (municipality of Sofia) - Ms. Ivancheva and Ms. Petrova - in a humiliating way. Before becoming mayors, these women were social activists fighting for a greener Mladost. They were among the few mayors endorsed by civil society and independent of a political party. The operation for their arrest was led by the then head of the Specialized Prosecutor's Office Ivan Geshev who was promoted to Deputy General Prosecutor three months after this operation. The mayors were kept in custody almost to the end of the trial and subjected to inhuman and degrading treatment. ${ }^{118}$

In November 2018, the Specialized Criminal Court ruled the women could be released from custody, but a few hours later the Specialized Court of Appeal quashed the ruling. After public protests, the President of the Supreme Court of Cassation Lozan Panov launched an inquiry pursuant to Article 114(9) of the Law on the Judiciary under which the Supreme Court has a mandate to check the administrative practices of the courts of appeal. ${ }^{119}$ The Specialized Prosecutor's Office publicly instructed the court not to cooperate which violates the hierarchy of Bulgaria's justice system. ${ }^{120}$ Despite these difficulties, the Committee sent by the Supreme Court discovered a serious case of malpractice: the Specialized Criminal Court of Appeal had quashed the ruling before the

\footnotetext{
115 Ibid, at 260.

116 Ibid, at 262.

$117 \mathrm{COM}(2016) 40$ final, at 12; $\operatorname{COM}(2017) 750$ final, at 8.

118 The case is mentioned in the 2018 Human Rights Report on Bulgaria by the US State Department under the heading 'arbitrary arrest and detention', https://www.state.gov/reports/2018-country-reports-onhuman-rights-practices/bulgaria/.

119 Press release by the Supreme Court of Cassation, 29 November 2018,

http://www.vks.bg/vks_p02 0546.htm.

120 They sent a letter to the court and put a press release on their website. After public uproar, they removed it. The press release is quoted here: The Prosecution Recommended Judges Not to Cooperate with Panov's Inquiry (2018),

https://www.dnevnik.bg/bulgaria/2018/11/29/3353918 prokuraturata preporucha na sudii da ne $\mathrm{s}$ e ostaviat na/.
} 
ruling was even fully drafted by the lower instance. ${ }^{121}$ Four days after the Committee of the Supreme Court published its report, the SJC judicial college initiated proceedings against the President of the Supreme Court of Cassation to establish if he threatened judicial independence by initiating the above inquiry which is striking considering the Specialized Criminal Court of Appeal and the Prosecutor's Office were the ones violating the law. ${ }^{122}$

The two mayors were accused of taking a bribe which they allegedly demanded to provide a construction permit. ${ }^{123}$ There were two witnesses - the entrepreneur who needed the permit and another person who was the intermediary. The entrepreneur admitted the mayors never asked him for a bribe directly, but through the intermediary, which, essentially, made the intermediary the key witness. After the start of the trial phase, the intermediary said that he was not questioned before a lawyer and that his witness statements against the mayors were extracted under threats by prosecutors, so he retracted them. Despite this, the Specialized Criminal Court credited the witness statements ${ }^{124}$ and sentenced the mayor to 20 years in jail and the deputy mayor - to 15 years. The judge also ordered the permanent arrest of the mayors, even though a verdict enters into force only after the third instance, with the argument the mayors could hide from justice because they had publicly argued the trial was unfair and because they benefited from public support, which 'created an organizational opportunity to defend a decision to hide from justice on their part'. ${ }^{125}$

After the verdict was handed down, there was a street protest and many prominent civil society members took a public stand - a former judge identified 'phenomena and paradoxes in the proceedings, which [could not] exist in a normal justice system', ${ }^{126}$ an established professor of political science argued that 'the European idea [could not] exist if there [were] political prisoners and special repressive bodies,' etc. ${ }^{127}$ In response, both the Specialized Court and the Specialized Court of Appeal published a poem addressed to Bulgarian citizens which defends the specialized courts. ${ }^{128}$ Disregarding the genre of expression which does not necessarily inspire the level of gravitas expected from a court, it is striking that the Specialized Court of Appeal defended the lower instance considering it would examine the mayors' verdict on appeal.

Furthermore, shortly after the verdict was handed down, Radio Free Europe Bulgaria reported that the entrepreneur who needed the construction permit had a

\footnotetext{
${ }^{121}$ Report by the Supreme Court of Cassation, 10 December 2018, http://www.vks.bg/vks p02 0553.htm.

122 Verbatim Report of the Judicial College No. 41, 14 December 2018.

123 See Motivation on Verdict on Case No. 2617/18, 1-2.

124 Ibid, 82-83.

125 Protocol of 15 April 2019 on Case No. 2617/18, 6-7.

${ }_{126}$ P Obretenov, Judge Hinov Sentenced to Silence Not Only the Indicted but Society as a Whole (2019).

127 E Dainov, Justice à la GERB and justice à la Staline (2019), https://clubz.bg/81862pravosydieto ala gerb i pravosydieto ala stalin.

${ }_{128}$ Press releases of 18 April 2019.
} 
business relationship with the wife of the prosecutor in the case - Ivan Geshev. ${ }^{129}$ This circumstance, which the prosecutor had not declared, is either a conflict of interest ${ }^{130}$ or, depending on intent, evidence of crime (framing). Because of the structure of the Prosecutor's Office and the dependencies of the SJC, an inquiry is impossible in practice.

Overall, the picture, which emerges from this case, at least from publicly available information, does not seem to evidence fighting high-level corruption. Rather, it seems to indicate lack of equality before the law, lack of separation of powers, disrespect for the hierarchy of the justice system, as well as breaches of fundamental rights.

\section{$5 \quad$ LESSONS FROM THE CVM}

The above discussion calls for a reflection about the usefulness of the CVM in addressing threats to the rule of law. The Commission has already faced criticism about its approach towards the rule of law crises in Poland and in Hungary. Halmai underscores that the Rule of Law Framework did not achieve anything which 'considerably undermined not only the legitimacy of the Commission, but also that of the entire rule of law oversight mechanism'. ${ }^{131}$ In light of the same framework, Uitz contends that 'the dialogic approach preferred by European constitutional actors poses a serious methodological challenge for confirming a threat to or a violation of the rule of law'. ${ }^{132}$ Notably, '[w] hether [national actors] are sincere about trying to comply with European minimum standards or are merely feigning cooperation, these actors ultimately use European frameworks and processes for their own political purposes to build illiberal democracies inside the EU'. ${ }^{133}$

Based on our analysis, we can raise similar concerns about the CVM which is also anchored in dialogue. By stalling compliance with some recommendations and by pretending to comply with others, Bulgaria managed to increase the excessive powers of the Prosecutor's Office, undermine judicial independence, and solidify the opportunities for political influence on the justice system. Meanwhile, the Commission did not insist on some recommendations, forgot to follow up on others, and marked as progress reforms, which, if analysed in detail, undermine the rule of law.

One may suspect that there is a design fault in the CVM itself - how is information gathered?; how is it assessed?; is the mechanism prone to political influence? When the latest rather positive 2018 CVM on Bulgaria was released, Hristo Ivanov, the only

129 Ivan Geshev is Linked to the Main Witness in the Ivancheva Case (2019), https://www.svobodnaevropa.bg/a/29947519.html.

130 Article 9.1 of the Code of Ethics of Bulgarian Magistrates; Article 175b and 175c of the Law on the Judiciary.

${ }^{131}$ Halmai, n.11 above, at 2; The Framework was designed as a mechanism of assessing whether a Member State has endangered the rule of law to such extent that Article 7 of the TEU should be triggered. See the Commission's Communication entitled 'A New EU Framework to Strengthen the Rule of Law' (COM(2014)158 final).

132 Uitz, n. 12 above, at 8.

$133 \mathrm{Ibid}$, at 12. 
Minister of Justice in Borissov's governments who pushed for more substantive reform, published a highly critical opinion piece. He contended:

The current Commission, which is dominated by the omnivorous EPP, had no political will to press Bulgaria's government for reforms. Juncker himself has a superficial attitude to questions of corruption and political principles. In the capitals of the bigger Member States, there is an understanding that so long as Bulgaria is not a member of Schengen, the question whether there is rule of law concerns [only Bulgarians]. ${ }^{134}$

In the same statement, Ivanov shared that in 2015, the Commission refused his request to include recommendations for a reform of the Prosecutor's Office in the CVM. ${ }^{135}$

These are the words of a minister who was the point of contact for implementing the CVM - as a person from the kitchen of this mechanism, he is well-placed to know its pitfalls. Both Viktor Orbàn's Fidesz and Borissov's GERB belong to the EPP. Unlike Orbàn, however, Borissov never engaged in anti-EU rhetoric and built strong relations with the EPP by making compromises such as accepting mandatory migrant quotas. ${ }^{136}$ This may shed some light on why the Commission neither had political will to push for real reforms in Bulgaria nor an interest in publicly recognizing the troublesome developments in the country. ${ }^{137}$ The Commission's complicity with Borissov's government is quite visible in the Yaneva Gate controversy discussed above. It is also noticeable in its decision to provisionally close benchmark one (judicial independence) in 2018 despite ample evidence of harassment of judges and despite the fact that the initial goal set in Decision 2006/929/EC of 13 December 2006, which specified the benchmarks, was a constitutional reform ensuring judicial independence. As explained above, the latter did not take place.

Beyond the role of politics, one may also question if the Commission has the capacity to adequately identify and monitor threats to the rule of law. It is important to mention that the Parliamentary Research Service at the European Parliament carried out an assessment of the CVM, which was published in 2018.138 Regarding Bulgaria, it observed that civil society was concerned that the 'vagueness of the CVM benchmarks ... allowed the Bulgarian government to continuously pass reform acts or adopt other measures that in theory contribute to achieving the CVM goals without actually changing institutional practice on the ground'. ${ }^{139}$ It also stressed that civil society views the CVM as

134 H Ivanov, The CVM: A Fit of Institutional Sciatica (2018), https://clubz.bg/75830dokladyt na ek tejyk_ppictyp_na inctitycionalen ishiac (translation my own).

135 Ibid.

${ }^{136}$ A Danaj, K Lazányi \& S Bilan, Euroscepticism and Populism in Hungary: The Analysis of the Prime Minister's Discourse, 11(1) Journal of International Studies 240-247 (2018).

${ }_{137}$ Scholars have already pointed out how party politics on a federal level may explain why authoritarian enclaves may persist even in democratic unions. See D Kelemen, Europe's Other Democratic Deficit: National Authoritarianism in Europe's Democratic Union, 52 Government and Opposition 215 (2017).

${ }_{138}$ 'Assessment of the 10 years' cooperation and verification mechanism for Bulgaria and Romania', DOI: $10.2861 / 44295$.

139 Ibid, at 41 . 
a 'a rather institutionalised mechanism, which is losing credibility as it continues to achieve only limited results'. ${ }^{140}$

The benchmarks are not only vague, but also overlap. Moreover, noncompliance with CVM recommendations is not punished in any way, which allows countries to stall arguably, the main reason why Progress Reports during the accession talks with Bulgaria and Romania were a successful instrument was the fine balance between threats and rewards..$^{141}$ Nevertheless, the fact that the Commission marks pseudo reforms or reforms undermining the rule of law as progress seems to indicate it has trouble navigating the Bulgarian legal landscape and/or it credits the claims by Bulgaria's government without verifying them. It is difficult to understand how a reform of Bulgaria's criminal law, which jeopardizes fundamental rights, was marked as progress and as a reason to provisionally close benchmark two (legal framework). It is also problematic that while it is aware of the longstanding issues of Bulgaria's Prosecutor's Office, the Commission has given the same office the lead to reform itself and to propose legislation which affects its powers.

Overall, the CVM has many pitfalls which put to question its viability and which do not make it a desirable mechanism to help other Member States strengthen their own rule of law. Moreover, if indeed the Juncker Commission lifts the mechanism for Bulgaria before the end of its term, this will serve as further proof that the CVM has been hijacked for political reasons. Bulgaria's experience may come to show that rule of law decline not only depends on the conduct of the individual Member State, but also on the actions and omissions of a serving Commission, which, similarly to Member States, may also misuse the EU legal framework. Furthermore, Bulgaria's CVM experience sheds light on some of the challenges which may arise if the Commission introduces a different monitoring mechanism for all Member States. While its precise scope and methodology remain to be defined, one may fear that it will exhibit the same weaknesses identified in Bulgaria's CVM. ${ }^{142}$

\section{CONCLUSION}

By using Bulgaria's CVM as a case study, this article showcased why mere monitoring is not a viable mechanism to strengthen the rule of law in other EU Member States. Notably, it examined three systemic threats to Bulgaria's rule of law, which have not been adequately addressed by the CVM - the excessive, uncontrollable powers of the

\footnotetext{
140 Ibid.

${ }^{141}$ The rewards can be divided in two categories: accession advancement rewards (opening and closing of chapters in the negotiation process) and financial rewards. The decoupling of Bulgaria and Romania from other East European candidate States as well as the safeguard clauses in their Treaty on Accession were part of the threats. See Gateva, n. 19 above, at 93.

${ }_{142}$ A brief overview of the likely shape of the mechanism has been provided in Communication on 'Strengthening the rule of law within the Union: A blueprint for action', COM(2019) 343 final, at 9-12. It bears a strong resemblance to the CVM.
} 
Prosecutor's Office, the political dependencies of judicial councils, as well as the capture of the courts.

On the one hand, it appears that the Commission has underestimated key structural problems of Bulgaria's justice system. On the other hand, it has verified as progress reforms, which either preserve the existing structural problems or further undermine the rule of law. As a result, Bulgaria's 'hooligan' post-accession behaviour, in the words of Venelin Ganev, ${ }^{143}$ has not been corrected. Borissov's governments added further tools to their autocratic arsenal which allows arbitrary prosecution and sentencing of inconvenient opponents.

One may seek the weaknesses of the CVM in its design - there appears to be a problem of assessment of threats to the rule of law, which is either related to the Commission's difficulty to identify such threats or to the fact that the mechanism itself is prone to political capture. The sad result is that twelve years after admission to the EU, Bulgaria still has not fulfilled the accession criteria.

143 Ganev, n. 31 above. 